\title{
European Urbanities Since 1945: A Commentary
}

Europe's history since 1945 has most commonly been seen through the prism of international politics - above all the politics of the Cold War - and economic change, from post-war reconstruction to late twentieth-century deindustrialisation. Urban history has been tangential to these accounts. Hence Leif Jerram's call to arms in his book Streetlife, published in 2011: 'It is time to put the where into the what and why of history'. The history of Europe's twentieth century, Jerram declared, happened 'in the streets and factories, cinemas and nightclubs, housing estates and suburbs, offices and living rooms, shops and swimming baths of Europe's booming cities'. ${ }^{1}$ This collection of articles represents a considered response to Jerram's iconoclastic challenge.

Geographically the essays range across Britain, France, the Netherlands, the Soviet Union and West Germany; temporally they refer to the period between the 1940s and the 1970s. In content and approach they steer clear of ideal types, whether of the 'European city' or the 'socialist/capitalist city', though certain typologies are apparent, as in the notion of West European 'cities of choice' or the distinction in post-war reconstruction between warzone cities and distant industrial centres in the Soviet Union. As a contribution to an understanding of European urbanities post-1945 what the essays collectively offer is an encouragement to think both comparatively and transnationally about the processes and experiences of 'urbanization', which requires us to identify commonalities and differences across time and space. In this brief commentary I want to examine three thematic issues raised by the articles, related to planning, welfare and migration. In conclusion, I shall reflect briefly on the periodization of European urban history since 1945 in the light of this discussion.

The theme of planning forms part of every paper to a greater or lesser extent. It is a historical commonplace that the widespread destruction of Europe's cities during the Second World War was a major impetus to post-war reconstruction and to city planning in particular. What is not always emphasized, however, is that the scale of destruction and the nature of subsequent planned redevelopment differed significantly across the Continent. In Britain only the bombing of Coventry could compare with the scale of devastation, and civilian deaths, suffered not only in large German cities like Hamburg and Dresden but also in smaller centres such as Darmstadt and Kassel. ${ }^{2}$ As in

\footnotetext{
${ }^{1}$ Leif Jerram, Streetlife: The Untold History of Europe's Twentieth Century (Oxford: Oxford University Press, 2011), 4.

${ }^{2}$ Amongst a large and controversial literature see Jörg Arnold, The Allied War and Urban Memory: The Legacy of Strategic Bombing in Germany (Cambridge: Cambridge University Press, 2011).
} 
Germany, much of the urban fabric in the Soviet Union was destroyed by the war so that an estimated 25 million people were homeless at its end, though many towns and cities emerged unscathed, such as Magnitogorsk and Syrzan', and indeed expanded in physical and demographic terms during wartime. Yet across Europe, in the two decades after 1945, radical reconstruction programmes were undertaken not only in ruined cities but also where no war damage had occurred.

From the vantage point of city planning, in fact, 1945 was not so much a turning-point as a catalyst to ideas and forms of expertise that were already in wide circulation in Europe and abroad by the 1930s. Two dimensions stand out especially. One was the policies of large-scale slum clearance applied in cities in Britain, Germany and the United States during the 1930s which proved to be preliminary steps in state and city-led programmes of what was to become known in the 1950s as 'urban renewal', lasting in many cases till the 1980s. The second was the rapid take-up of modernist ideas of architecture and urban planning via documents such as the Athens Charter of 1933, promoted by the Congrès International d'Architecture Moderne (CIAM) with its call for the creation of the 'functional city' based on principles of zoning, rehousing and circulation. ${ }^{3}$ Well before 1945 , then, there existed something like an emergent international consensus on urban reform and reconstruction which transcended Europe's political divisions, including Soviet Russia and even, in some respects, Nazi Germany. In his coruscating critique of modern statecraft James C. Scott has observed that 'high-modernist faith was no respecter of traditional political boundaries; it could be found across the political spectrum from left to right but particularly among those who wanted to use state power to bring about huge utopian in people's work habits, living patterns, moral conduct, and worldview'. ${ }^{4}$

This did not mean, however, that similar historical processes played out in the same way in different urban and political contexts. One basic difference between East and West was the significance of private urban developers in shaping city centre reconstruction, as Author A highlights in discussing the redevelopment of the Spuikwartier quarter at the heart of the 1960s Hague. Elsewhere Peter Mandler has rightly pointed out that in much of northern and western Europe in the 1950s and 1960s state-led and municipal planning existed alongside its apparent obverse,

\footnotetext{
${ }^{3}$ Eric Mumford, The CIAM Discourse on Urbanism, 1928-1960 (Cambridge, Mass.: MIT Press, 2002).

${ }^{4}$ James C. Scott, Seeing Like a State: How Certain Schemes to Improve the Human Condition Have Failed (New Haven: Yale University Press, 1998), 5.
} 
private speculative development especially evident in large-scale shopping schemes. ${ }^{5}$ In contrast, as Author F points out, post-war Soviet towns and cities might have appeared to share many planning features with their counterparts elsewhere in Europe, but in practical matters of financing and welfare as well as ideological commitments to equality, Soviet post-war urbanism departed significantly from Western models. It also changed over time, the communist idealism of urban planning under Krushchev giving way to a more pragmatic approach during the Brezhnev era in the later 1960s and 1970s. Just as the experience of Soviet welfare was shaped by the spaces of the offices where welfare was dispensed, so the articles here underline that the historical meanings of urbanism were always context-dependent.

In other respects too, the transnational and the local were bound together in post-war European cities through the networks of planning. As Daniel Rodgers brilliantly showed in Atlantic Crossings, late nineteenth and early twentieth-century urban reform was essentially an international and inter-urban affair, involving France, Germany, Britain and the United States in a North 'Atlantic economy', 'an intense, transnational traffic in reform ideas, policies, and legislative devices. For a moment London's East End and New York's Lower East Side; the "black country" of Pittsburgh, Essen and Birmingham; and university debates and chancery discussions in Paris, Washington, London and Berlin formed a world of common referents'. ${ }^{6}$ This exchange continued after 1945, albeit in a very different geo-political context. As the articles here consistently suggest, public housing remained at the top of the urban agenda wherever one looked and in Western Europe this gave particular valency to the social democratic impulses from Scandinavia, especially Sweden. While the British new towns and earlier garden city movements exercised influence on planning internationally in the 1950s and 1960s, including Soviet Russia, Swedish vernacular style and prefabrication techniques of building came to have strong appeal to planners of public housing in the largely Labour-dominated cities of northern England such as Newcastle-upon-Tyne and Sheffield. Yet as Author D shows, 'Swedish modern' was often contested in architectural circles and proved difficult to embed in the conditions of British industrial cities, especially when combined with the drive to high-rise in the 1960s. Local politics and culture again worked to inflect transnational exchanges in unexpected and sometimes unwelcome directions. By the 1960s housing was being rivalled by the rise of motor traffic as the most pressing problem confronting planners: roads and cars became the driving force

\footnotetext{
${ }^{5}$ Peter Mandler, 'New Towns for Old' in Beckie Conekin, Frank Mort and Chris Waters (eds) Moments of Modernity: Reconstructing Britain, 1945-64 (London: Rivers Oram Press, 1999), 213-14.

${ }^{6}$ Daniel T. Rodgers, Atlantic Crossings: Social Politics in a Progressive Age (Cambridge, Mass.: Harvard University Press, 1998), 3, 4. See also Pierre-Yves Saunier and Shane Ewen (eds.), Another Global City: Historical Explorations into the Transnational Municipal Moment, 1850-2000 (Basingstoke: Palgrave, 2008).
} 
behind reconstruction in many European cities. Once again, techniques for controlling urban traffic might be commonly shared - ring roads were a ubiquitous feature of large cities from Moscow to Brussels, often inspired by the introduction of American models of traffic engineering from the early 1950 s - but they had to operate within very diverse cultures of automobility and to adapt to different urban morphologies. While the advent of the 'motor age' was widely celebrated by politicians, it also occasioned dire predictions of the effects of mass automobility on Europe's towns and cities, as Author A notes of Dutch planning from the late 1950 s. $^{7}$

The articles in this special issue also make clear how intimately urban planning was implicated with social planning in the form of welfare. It is a commonplace that the years after 1945 saw the introduction of a welfare state in different guises across many - though far from all European countries, but it is not always appreciated how far this was an urban rather than merely a national institution. In the study of the Soviet welfare system Author F makes the point trenchantly: 'welfare shaped the Soviet and the Soviet city shaped the welfare system'. Cities provided the locus for the attempt to create a total welfare society in which all social needs would be met, from the factory to the microdistrict and the kindergarten; 'socialism was in the first instance an urban project'. Yet it was not only in the Eastern bloc that welfare was identified pre-eminently with urban society. In Western Europe too, the rediscovery of 'islands of poverty' in the midst of the welfare state from the late 1950s was synonymous with the naming of new urban spaces, 'grey zones', bidonvilles, or the 'inner city', terms that increasingly reflected the growing ethnicisation of many West European cities and the linkage of poverty with the presence of minority populations. These identifications were especially marked in the sociology of poverty that developed from the early 1960s. '[E]xperts assumed', observes Author C, that "in all large modern cities" there was an emergent "subculture of poverty" that transcended national borders'. In France and Britain the 'rediscovery' of poverty was led not by state officials but by voluntary associations, often an improbable coalition of church groups, charities and left activists. ${ }^{8}$ The centrality of housing to planning and political calculations at the period reinforced the tendency to connect urban policy

\footnotetext{
${ }^{7}$ For examples of contemporary debate see Simon Gunn, 'The Buchanan Report, Environment and the Problem of Traffic in 1960s Britain', Twentieth Century British History, 22 (2011), 521-542; Barbara Schmucki, 'Cities as Traffic Machines: Urban Transport Planning in East and West Germany' in Colin Divall and Winston Bond (eds), Suburbanizing the Masses: Public Transport and Urban development in Historical Perspective (Aldershot: Ashgate, 2003), 149-170.

${ }^{8}$ In some cases those involved could encompass all three dimensions. The housing charity Shelter was founded in London in 1966 by Bruce Kenrick, a minister of the United Reform Church who was also a supporter of the Cuban revolution and Latin American liberation theology. On the crisis in London's housing in the 1960 s see Jerry White, London in the Twentieth Century (London: Vintage, 2008), 46-51.
} 
with welfare. Housing, poverty and (increasingly) 'race' came to form an important focus for urban anxieties in north-west European cities, as they would more widely across the continent at a later date.

The obverse of the rediscovery of poverty was the rediscovery of 'affluence'. And like poverty, 'affluence' too was viewed as a problem, especially among the New (and some sections of the old) Left. While sociologists in mid-1960s Britain anxiously investigated the figure of the 'affluent worker' as an index of working-class embourgeoisement, in France Pierre Bourdieu embarked on the most ambitious study yet of consumerism, taste and social difference, later to be published as La Distinction. ${ }^{9}$ As Author B observes, a culture of affluence in West European cities in the 1960s worked itself out in relation to diverse concepts of 'choice' and individualism. On the one hand it shaped the idea of choosing your own home, its décor, and the right to a home-centred privacy enjoyed with family and selective friends. On the other hand, 'cities of choice' also produced an alternative to this conservative, domesticated individualism in the form of the radicalism of the New Left with its attraction to communal living and squatting, experiments with drugs and sex and commitment to grassroots urban politics. ${ }^{10}$ While in the longer term the lines between these two 'elective affinities' proved not so sharp, blending from the 1980s into a new urban consumer culture of organic food and street festivals, so different varieties of individualism rested on the safety net of the welfare state; affluence and welfare were intimately connected, not discrete categories. 'Elective affinities' of consumption and affect, then, provide a further lens through which the history of postwar urbanities, of Western Europe especially, can be written.

The third critical theme of post-war urban history is migration, the transformation of Europe's cities by successive waves of people who became - and made themselves - urban-dwellers. It is not a theme which plays a leading part in these essays but it nonetheless represents a repeated, important motif in them, from the great movements of workers to Soviet industrial and company towns such as Magnitogorsk and Kuibyshev to the bidonvilles of French cities, like Noisy-le-Grand outside Paris which housed immigrants from North Africa and all points south from the late 1950s. Governments and city authorities routinely represented migrants as a social problem but they provided much of the lifeblood and dynamism of urban centres. 'Accelerating urbanization in the

\footnotetext{
9 John H. Goldthorpe et al., The Affluent Worker, 2 vols. (Cambridge: Cambridge University Press, 1968); Pierre Bourdieu, La Distinction. Critique Sociale du Jugement (Paris: Editions de Minuit, 1979).

${ }^{10}$ The historiography of alternative lifestyles in the 1960s and 1970s is expanding rapidly. See for example John Davis and Anette Warring, 'Living Utopia: Communal Living in Britain and Denmark', Cultural and Social History, 8:4 (2011), 513-530; Emily Pugh, Architecture, Politics and Identity in Divided Berlin (Pittsburgh: University of Pittsburgh Press, 2014), especially ch.5.
} 
modern era', Peter Clark has written, 'was only made possible by a huge influx of immigrants'. ${ }^{11}$ Migrants to post-1945 European cities came, of course, from very different places, and above all from the countryside. In Italy, for example, it has been estimated that between 1995 and 1971 some 9 million people undertook inter-regional migration mainly to the 'industrial triangle' of Turin, Milan and Genoa. ${ }^{12}$ Across southern and much of eastern Europe these were the years in which the peasantry all but disappeared, the beneficiaries in demographic terms being the continent's urban agglomerations. Populations were attracted from Europe's borders, notably the 750,000 Turkish gastarbeiters to West Germany who settled in industrial regions such as the Ruhr and BadenWürttemberg between 1961 and 1973. Among former colonial powers, notably France, Britain, Netherlands, Belgium, and Portugal, decolonisation post-1945 led in some cases to sizeable migrations to the metropolitan heartlands, prefiguring the emergence of multi-ethnic, multi-cultural urban societies in the late twentieth century. ${ }^{13}$ The urban consequences of such shifts were complex: substantial immigration disturbed the plans of city policy-makers whose designs were predicated on a stable (implicitly white) population. And as Jordanna Bailkin has recently argued in the case of Britain, decolonization had major effects on the post-war welfare state in specific areas such as child welfare, education and the criminal law. ${ }^{14}$ Thus the study of Europe's post-war urbanities brings together histories of planning, empire and welfare that have traditionally been kept apart, complicating each of those histories in the process.

Finally, what might this collection tell us about the periodization of urban change in mid- and later twentieth century Europe? In the first place, as I have already suggested, 1945 did not represent an historical caesura, despite the mass destruction of many European cities, but rather a continuation of policies and practices already instigated in the 1930s in domains such as housing, new towns and microdistricts (or neighbourhood units). A number of the essays here confirm the 'modern' both as a desirable end-state of urbanism and as a process ('reflexive modernisation', 'modernism') between the 1930s and 1970s. The 'modern' here encompassed different levels of practice, from planning and design to lifestyle. But as the introductory essay implies, the decades after 1970 saw a further shift as the urban modern came under selective attack from preservationists, activists and others. Manuel Castells' The Urban Question, originally published in

\footnotetext{
${ }^{11}$ Peter Clark, European Cities and Towns 400-2000 (Oxford: Oxford University Press, 2009), 282.

${ }^{12}$ Paul Ginsborg, A History of Contemporary Italy: Society and Politics 1943-1988 (New York: Palgrave Macmillan, 2003), 219.

${ }^{13}$ The work of Elizabeth Buettner is important here. See her “'Going for an Indian": South Asian Restaurants and the Limits of Multiculturalism in Britain', Journal of Modern History, 80:4 (2008), 865-901 and forthcoming monograph Europe After Empire: Decolonization, Society and Culture (Cambridge, Cambridge University Press, 2014).

${ }^{14}$ Jordanna Bailkin, The Afterlife of Empire (Berkeley, Ca.: University of California Press, 2012),
} 
France in 1972, with its emphasis on the city as the site of new forms of social struggle, represented one radical dimension of this historical moment. ${ }^{15}$ Equally instructive, however, was Jean-François Lyotard's La Condition Postmoderne, published in $1979 .{ }^{16}$ Originally taken as a philosophical reflection on the future of knowledge, La Condition Postmoderne can also be read as an historical commentary on the contemporary implosion of modernising projects, including that of urban reform. Lyotard's definition of the postmodern as 'incredulity towards metanarratives', including those propagated under the name of socialism, science and capitalism, linked it to the move towards a technocratic instrumentality which the essays suggest was characteristic not only of West European urbanism but also the Soviet Union under Brezhnev in the 1970s. One might therefore think of European cities in the 1970s and 1980s as laboratories for new kinds of social and political experimentation, of technocratic intervention, communitarianism and neo-liberalism, developed beyond or outside the precepts of the modern. But these are histories that are yet to be written.

\footnotetext{
${ }^{15}$ Manuel Castells, La Question Urbaine (Paris: François Maspero, 1972).

${ }^{16}$ Jean-François Lyotard, La Condition Postmoderne: Rapport Sur Le Savoir (Paris: Editions de Minuit, 1979).
} 